\title{
EVALUATION OF PHICOCYANIN PRODUCTION BY Anabaena variabilis USING DIFFERENT ORGANIC CARBON SOURCES
}

\section{AVALIAÇÃO DA PRODUÇÃO DE FICOCIANINA POR Anabaena variabilis UTILIZANDO DIFERENTES FONTES DE CARBONO ORGÂNICO}

\author{
W. R. CUNHA ${ }^{1 *}$, T. A. TEIXEIRA ${ }^{2}$, A. G. COTTAS $^{2}$ and J. S. FERREIRA ${ }^{2}$ \\ ${ }^{1}$ Federal University of Uberlândia, Institute of Biotechnology, Uberlândia, Minas Gerais, Brazil \\ ${ }^{2}$ Federal University of Uberlândia, Faculty of Chemical Engineering, Uberlândia, Minas Gerais, Brazil
}

${ }^{*}$ Corresponding author. Federal University of Uberlândia, Institute of Biotechnology, Uberlândia, Minas Gerais, Brazil, Phone: +55 31971763505

e-mail address: warlleyrcunha@gmail.com (W.R. Cunha).

**Preliminary version of this work was published in: Anais do XIII Congresso Brasileiro de Engenharia Química em Iniciação Cientifica. São Paulo: Blucher, 2019. ISSN 2359-1757, DOI 10.5151/cobecic2019-PBIO51

\begin{tabular}{l} 
A R T I C L E I N F O \\
\hline Article history: \\
Received 2020-07-31 \\
Accepted 2020-09-04 \\
Available online 2020-09-04 \\
pa lavras - chave \\
Ficocianina \\
Crescimento celular \\
Suplementação \\
ke ywords \\
Phycocyanin \\
Cell growth \\
Supplementation
\end{tabular}

\begin{abstract}
A B S T R A C T
Phycocyanin (PC) is one of the phycobiliproteins, pigments found in cyanobacteria, which can be used as natural dyes, antioxidants and fluorescent markers. This study aimed to investigate the effect of supplementation of the basal culture medium (BG110) of the cyanobacterium Anabaena variabilis with different sources of organic carbon in concentration of $1 \mathrm{~g} \mathrm{~L}^{-1}$, evaluating the production of biomass and PC. The best condition obtained was the medium supplemented with glucose that produced $75.36 \mathrm{mg} \mathrm{g}^{-1} \mathrm{PC}$, about 5 times greater than the control with $14.57 \mathrm{mg} \mathrm{g}^{-1}$ PC. All supplemented media also showed higher biomass production compared to the basal medium, again to stand out for the glucose medium, presenting $0.29 \mathrm{~g} \mathrm{~L}^{-1}$ of dry biomass.

R E S UM O

A ficocianina (FC) é uma das ficobiliproteinas, pigmentos encontrados nas cianobactérias, que podem ser usadas como corantes naturais, antioxidantes e marcadores fluorescentes. Este estudo teve como objetivo investigar o efeito da suplementação do meio de cultura basal (BG110) da cianobactéria Anabaena variabilis com diferentes fontes de carbono orgânico em concentração de $1 \mathrm{~g} \mathrm{~L}^{-1}$, de modo a avaliar à produção de biomassa e FC. A melhor condição obtida foi o meio suplementado com glicose que produziu 75,36 $\mathrm{mg} \mathrm{g}^{-1} \mathrm{FC}$, cerca de 5 vezes maior que o controle com 14,57 $\mathrm{mg} \mathrm{g}^{-1} \mathrm{FC}$. Todos os meios suplementados também apresentaram maior produção de biomassa em comparação com o meio basal, novamente para destaque para o meio com glicose, apresentando $0,29 \mathrm{~g} \mathrm{~L}^{-1}$ de biomassa seca.
\end{abstract}




\section{INTRODUCTION}

Cyanobacteria are prokaryotic, unicellular and photosynthetic organisms found in the presence of light, with unicellular, multicellular or filamentous forms and producers of a wide variety of secondary metabolites with biotechnological application (Whitton and Potts, 2012). They are classified as microalgae and belong to the phylum Chlorophyta because they have chlorophyll and photosynthetic pigments such as phycobiliproteins, responsible for the photosynthesis process (Olaizola, 2003).

In general, cyanobacteria perform photosynthesis under autotrophic medium, using light energy and $\mathrm{CO}_{2}$ as a carbon source, mostly. Nevertheless, some strains may assimilate, depending on light, nutrients from organic compounds to maintain metabolism and can also grow in mixotrophic and heterotrophic environments (Prasanna et al., 2004; Skleryk et al., 2002). This advantage has been applied to increase the production of biomass, and secondary metabolites as hydrogen, exopolysaccharides and pigments (Manirafasha et al, 2016; Noreña-Caro and Benton, 2018). Cyanobacteria of the genus Anabaena produce a variety of products. The most studied are toxins, however, researchers have been dedicating to investigate the potential of these microorganisms in the production of bioactive further compounds, such as peptides, fatty acids, alkaloids and other metabolites (Jaiswal et al., 2008; Schrader and Dayan, 2009; Tan, 2007).

Among these metabolites, phycobiliproteins (PBP) stands out, they represent $50 \%$ of the total cellular protein of cyanobacteria. Phycobiliproteins are found in a complex structure called the tilacoidal membrane, which plays an important role in light capture and energy transfer for the photosynthesis reaction (Rastogi et al., 2015; Viskari and Colyer, 2003). The three main phycobiliproteins found in cyanobacteria are: phycoerythrin $\left(\mathrm{EF}, \gamma^{\prime m a x}=\sim 560 \mathrm{~nm}\right.$, red), phycocyanin $(\mathrm{PC}, \partial \mathrm{max}=\sim 615 \mathrm{~nm}$, blue) and allophycocyanin (APC, $\partial \max =\sim 650 \mathrm{~nm}$, light blue). Since the more prominent color is blue, cyanobacteria received the name of blue algae (Aryee et al., 2018; Kumar et al., 2014; Stal, 2007).

Phycocyanin (PC) has been the most studied PBP, due to properties such as antioxidant, non-toxic and anti-inflammatory potential. It has applications in the food industry as a natural dye for products such as chewing gum, desserts, candies, cake decoration, jellies and ice cream; in the cosmetic industry applied in lipsticks and eyeliners and the medical industry used as a marker in clinical diagnostics, in photodynamic therapy of tumors and immunoassay in fluorescent tubes (Ilter et al., 2018; Lauceri et al., 2018).

The synthesis of this bioactive compound can be evaluated in order to increase its production on an industrial scale, by addressing parameters such as light, medium composition, $\mathrm{pH}$, temperature and photoperiod. More specifically, about the composition, the carbon source influences the formation mainly of macronutrients, such as carbohydrates, lipids and proteins (Manirafasha et al., 2016; Pagels et al., 2019).

Among the media to cultivation of cyanobacterial biomass, the mineral medium $\mathrm{BG} 11_{0}$ is largely used, constituting a photoautotrophic culture. Nevertheless, the influence of mixotrophic environment, in which the carbon source is formed by inorganic and organic substances, has been evaluated in order to increase the productivity of biomass and products, like phycobiliproteins (Borsari et al., 2007; Rizzo et al., 2015).

This study aimed to evaluate the effect of supplementing basal culture medium of cyanobacteria Anabaena variabilis (BG110) using different organic carbon sources (glucose, lactose, fructose, sucrose and galactose), aiming to increase the production of biomass and phycocyanin $(\mathrm{PC})$.

\section{MATERIAL AND METHODS}

\subsection{Cyanobacterial cultivation and maintenance}

The cyanobacteria strain used, Anabaena variabilis ATCC 29413, was kindly donated by the Cyanobacteria and Phytotoxin Laboratory, from Institute of Oceanography, Federal University of Rio Grande (Rio Grande, Brazil)

The cultivation of cyanobacteria was carried out in BG11 0 basal medium, which is prepared by adding $1 \mathrm{~mL}$ of each of the following solutions: $\mathrm{K}_{2} \mathrm{HPO}_{4}\left(30.0 \mathrm{~g} \cdot \mathrm{L}^{-1}\right), \mathrm{MgSO}_{4} .7 \mathrm{H}_{2} \mathrm{O}$ $\left(75.0 \mathrm{~g} \cdot \mathrm{L}^{-1}\right), \mathrm{CaCl}_{2} .2 \mathrm{H}_{2} \mathrm{O}\left(36 \mathrm{~g} \cdot \mathrm{L}^{-1}\right)$, ferric ammonium citrate $(6$ g. $\mathrm{L}^{-1}$ ), Na 2 .EDTA (Ethylene Diamino Tetracetic Acid $\mathrm{Na}_{2}, 1$ $\left.\mathrm{g} \cdot \mathrm{L}^{-1}\right)$, citric acid $\left(6 \mathrm{~g} \cdot \mathrm{L}^{-1}\right), \mathrm{Na}_{2} \mathrm{CO}_{3}\left(20 \mathrm{~g} \cdot \mathrm{L}^{-1}\right)$ and trace metal solution. The trace metal solution contained $\mathrm{ZnSO}_{4} .7 \mathrm{H}_{2} \mathrm{O}$ $\left(0.222 \mathrm{~g} \cdot \mathrm{L}^{-1}\right), \mathrm{MnCl}_{2} .4 \mathrm{H}_{2} \mathrm{O}\left(1.81 \mathrm{~g} \cdot \mathrm{L}^{-1}\right), \mathrm{Na}_{2} \mathrm{MoO}_{4} \cdot 2 \mathrm{H}_{2} \mathrm{O}(0.39$ $\left.\mathrm{g} \cdot \mathrm{L}^{-1}\right), \mathrm{CuSO}_{4} .5 \mathrm{H}_{2} \mathrm{O}\left(0.079 \mathrm{~g} \cdot \mathrm{L}^{-1}\right), \mathrm{CoCl}_{2} .6 \mathrm{H}_{2} \mathrm{O}\left(0.04 \mathrm{~g} \cdot \mathrm{L}^{-1}\right)$ and $\mathrm{H}_{3} \mathrm{BO}_{3}\left(2.86 \mathrm{~g} \cdot \mathrm{L}^{-1}\right)$. The volume was completed with deionized water to $1 \mathrm{~L}$ and the final $\mathrm{pH}$ maintained between $7.4-7.6$ (Rippka et al., 1979).

The culture was kept in 250 and $500 \mathrm{~mL}$ cotton-plugged Erlenmeyer flasks, in a photoperiod chamber, with temperature controlled at $30{ }^{\circ} \mathrm{C}$, luminosity of 1,553 lux provided by white LED lamps with $12 \mathrm{~h}$ light/dark photoperiod, in an aerobic environment. The medium was renewed every 14 days.

\subsection{Cultivation conditions}

The strain maintained in basal medium (BG110) was used as inoculum in the experiments carried out to test the effect of different sources of organic carbon for the production of biomass and phycocyanin by fermentation.

The assays were performed in Erlenmeyers of $125 \mathrm{~mL}$, with a working volume of $50 \mathrm{~mL}$, with an inoculum volume of $20 \%$ (v/v), which corresponded to an initial cell concentration of $0.11 \mathrm{~g} \mathrm{~L}^{-1}$. It was prepared medium without adding the carbon

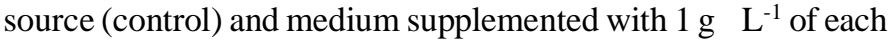
sugar. The sugars analyzed were: glucose, lactose, fructose, 
sucrose and galactose. Each condition was performed in triplicate under agitation of $150 \mathrm{rpm}$ in an orbital shaker; to $30{ }^{\circ} \mathrm{C}$; with light intensity of $1,533 \mathrm{lux}$; and a photoperiod of $12 \mathrm{~h} \mathrm{light/dark.}$

\subsection{Organic carbon quantification}

The quantification of sugars was performed by HPLC (High Performance Liquid Chromatography). The sample was filtered through a $0.22 \mu \mathrm{m}$ filter and injected into the Shimadzu chromatograph model LC-20A Pronience, equipped with SUPELCOGEL C-610H column and refractive index detector, with phosphoric acid solution $(0.1 \%)$ used as the mobile phase, with a pump flow of $0.5 \mathrm{~mL} / \mathrm{min}$, oven temperature of $32^{\circ} \mathrm{C}$ and injection volume of $20 \mu \mathrm{L}$.

\subsection{Cell growth analysis}

Cell concentration was analyzed at 2, 4, 6 and 8 days of fermentation. The biomass was determined by measuring optical density in a spectrophotometer (Shimadzu UV mini-1240, Shimadzu, Kyoto, Japan) with a wavelength of $750 \mathrm{~nm}$, and correlated with the dry cell mass concentration (g dry mass $\cdot \mathrm{L}^{-1}$ ) by a calibration curve (Hemlata e Fatma, 2009; Rizzo et al., 2015).

The experiments were carried out using a laminar flow chamber, previously cleaned with $70 \%$ alcohol and kept in ultraviolet light for $15 \mathrm{~min}$, with previously sterilized materials, in order to avoid contamination. For each assay, $5 \mathrm{~mL}$ samples were taken, and subsequently centrifuged at $5000 \mathrm{~g}$ and washed with distilled water three times in order to eliminate interferences from the culture medium during absorbance measurements on the spectrophotometer.

\subsection{PC production}

Since phycobiliproteins are intracellular compounds, in the last day of assay, PC extraction was performed by collecting $10 \mathrm{~mL}$ of culture suspension in a Falcon tube of $15 \mathrm{~mL}$ for freezing and thawing cycles combined with ultrasound, with 5 freezing cycles at $-15^{\circ} \mathrm{C}$ for $1.5 \mathrm{~h}$ and thawing in the bath ultrasonic at $25^{\circ} \mathrm{C}$ for $30 \mathrm{~min}$, using the $0.1 \mathrm{M}$ phosphate buffer pH 7.0 as the extracting solution (Cottas et al., 2020).

The extracted samples were analyzed by spectrophotometry (Shimadzu UV mini-1240) and the PC concentration $\left(\mathrm{mg} \cdot \mathrm{mL}^{-1}\right)$ was calculated according to the Equation 1 (Khazi et al., 2018).

$$
C_{P C}=\frac{A_{615}-0.474 \times A_{652}}{5.34}
$$

where A615 and A652 are respectively the characteristic wavelengths of phycocyanin and allophycocyanin.

\subsection{Statistical Analysis}

Statistical analyzes for mean difference analysis of biomass concentration and phycocyanin content, using the $95 \%$ confidence Tukey test, were performed by Statistica ${ }^{\circledR} 8.0$ Software.

\section{RESULTS AND DISCUSSION}

\subsection{Organic carbon quantification}

The consumption of carbon sources in different cultivation media over 6 days is shown in Table 1.

Table 1 - Carbon source consumption during 6 days in the cultivation of Anabaena variabilis.

\begin{tabular}{cccccc}
\hline $\begin{array}{c}\text { Time/ d } \\
\text { Carbon Source/ } \\
\mathbf{g} \cdot \mathbf{L}^{-\mathbf{1}}\end{array}$ & $\mathbf{0}$ & $\mathbf{2}$ & $\mathbf{4}$ & $\mathbf{6}$ & $\begin{array}{c}\text { Consumption/ } \\
\mathbf{\%}\end{array}$ \\
\hline $\begin{array}{c}\text { Glucose } \\
\text { Lactose }\end{array}$ & 1.00 & $0.81 \pm 0.02$ & $0.75 \pm 0.04$ & $0.43 \pm 0.01$ & 56.7 \\
Fructose & 1.00 & $0.66 \pm 0.01$ & $0.51 \pm 0.01$ & $0.47 \pm 0.01$ & 52.8 \\
Sucrose & 1.00 & $0.68 \pm 0.02$ & $0.47 \pm 0.02$ & $0.34 \pm 0.02$ & 66.2 \\
Galactose & 1.00 & $0.66 \pm 0.02$ & $0.60 \pm 0.02$ & $0.38 \pm 0.01$ & 61.7 \\
\hline
\end{tabular}

Note: Values represent mean \pm standard deviation, obtained by triplicate.

Table 1 shows that there was a consumption, in this increasing order of lactose, galactose, glucose, sucrose and fructose, indicating that the cyanobacterium of Anabaena variabilis can assimilate all sources of carbon tested.

These results corroborate the study by Chen et al. (2008), who studied supplementation to the culture medium of the strain of Anabaena sp. with different organic carbon sources at the initial concentration of $2 \mathrm{~g} \mathrm{~L}^{-1}$, obtaining that fructose was the preferred source of organic carbon for this strain, with almost $100 \%$ of substrate consumption in 8 days of cultivation, besides the consumption of sucrose in about $70 \%$ as the third most consumed organic carbon source. Khetkorn et al. (2010) found similar consumption behaviors to the present study analyzing the uptake of different sugars by Anabaena siamensis. These authors used sugar concentrations of $0.5 \mathrm{~g} \mathrm{~L}^{-1}$, obtaining $45 \%$ consumption for fructose, followed by sucrose and glucose with $25 \%$. Both authors discover that galactose and lactose may not be used as an organic carbon source since they found the lowest consumption by using this sugar. In the current work, $A$. variabilis showed the smallest consumption with lactose 
$(52.8 \%)$, but yet, it was considerable, since the consumption varied from $52.8 \%$ to $66.2 \%$.

Studies show that cyanobacteria can be successfully used in mixotrophic cultivation since they have genes responsible for the assimilation of organic carbon sources. This characteristic is an important ecological peculiarity that can be applied in the integration of wastewater treatment or reuse of by-products that are originated from agroindustrial sector as they are largely consisted by sugar (Muñoz-Marín et al., 2020).

\subsection{Growth of $A$. variabilis}

Growth curves for the A. variabilis strain in basal medium and supplemented media with different carbon sources are shown in Figure 1.

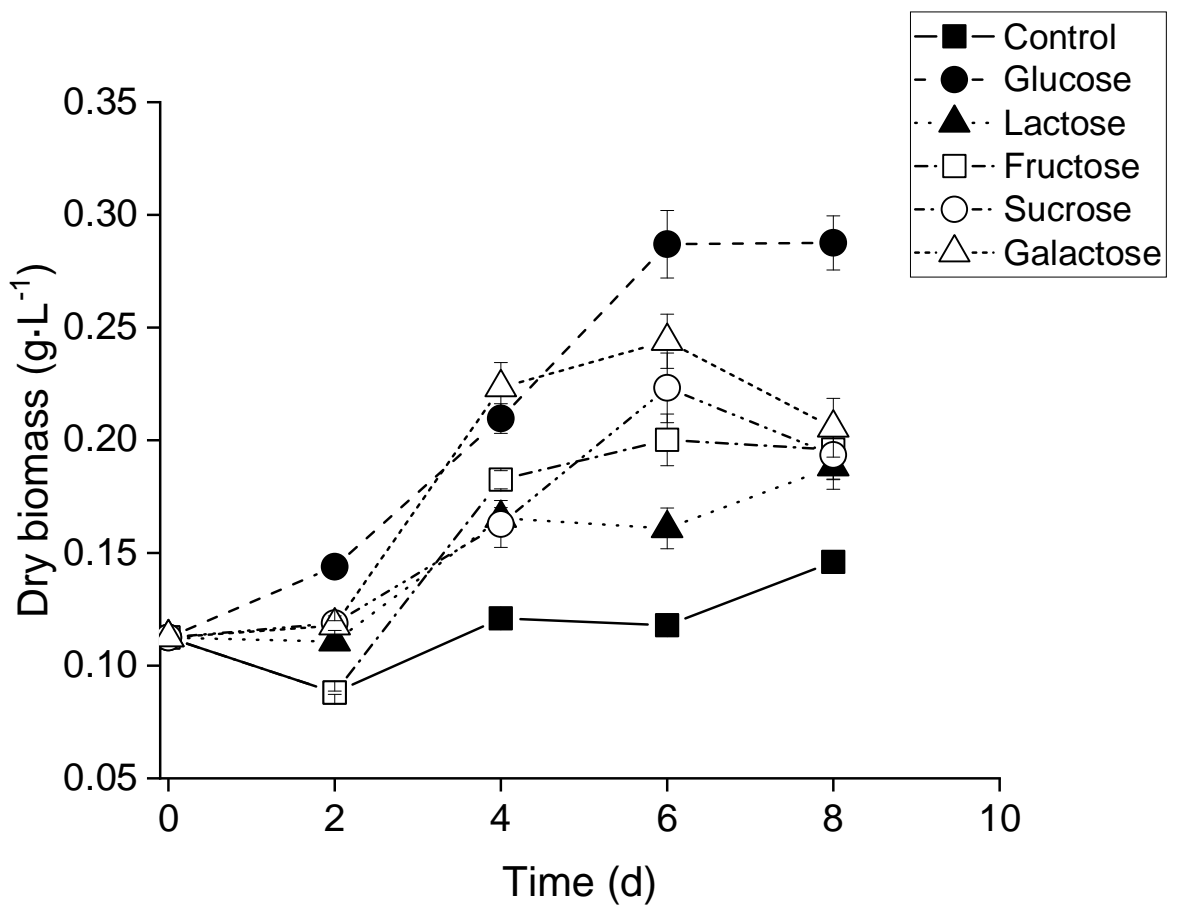

Figure 1 - Cell concentration obtained from $A$. variabilis under different culture media in 8 days. Values represent mean \pm standard deviation, obtained by triplicate.

Figure 1 shows that all supplemented media favored biomass growth and cell concentration was superior to the biomass content observed for the control medium at the end of 8 days. In the medium supplemented with glucose, cell concentration achieved the highest magnitude $\left(0.29 \mathrm{~g} \mathrm{~L}^{-1}\right)$, about 2 times higher than in the medium control $\left(0.15 \mathrm{~g} \mathrm{~L}^{-1}\right)$. It is noteworthy that glucose was not the most consumed sugar (Figure 1), but resulted in higher biomass growth.

This result corroborates the fact that the mixotrophic culture promotes an increase in cell concentration, in relation to the photoautrophic culture. The most studied source of organic carbon used to increase cell biomass is glucose. Kovac et al. (2017) observed that the addition of glucose $1.5 \mathrm{~g} \mathrm{~L}^{-1}$ to the control medium increased the biomass concentration of cyanobacteria of the genus Anabaena, with the C2 strain obtained an increase of $50 \%$ while the C5 strain obtained an increase of about $200 \%$ compared to the control with 35 days of cultivation. In the work developed by Vargas et al. (2018), that applied the strain Anabaena sp. showed that the best biomass yield was obtained from a temperature of $32{ }^{\circ} \mathrm{C}$ and $2.1 \mathrm{~g} \square \mathrm{L}^{-1}$ of glucose, reaching about $0.68 \mathrm{~g} \mathrm{~L}^{-1}, 1.3$ times higher than the control.
The other culture media supplemented (lactose, fructose, sucrose and galactose) showed no significant difference for cell concentration, reaching approximately $0.20 \mathrm{~g} \mathrm{~L}^{-1}$ of dry biomass after 8 days of cultivation, $25 \%$ higher than the control medium.

Further works proposed to analyze the possibility of using these sugars for the production of cellular biomass and obtained varied results. Sahu et al. (2007) observed that the cell growth rate of Anabaena sp. the medium supplemented with 5 $\mathrm{g} \square \mathrm{L}^{-1}$ of lactose was the highest, followed by the medium containing fructose. Khattar et al. (2015) observed that sucrose was the best carbon source for the growth of Anabaena. fertilissima, showing biomass concentration $30 \%$ higher in the presence of sucrose than the control cultures. Khetkorn et al. (2020) supplemented almost $11 \mathrm{~g} \mathrm{~L}^{-1}$ of fructose to the $\mathrm{BG} 11_{0}$ medium using Anabaena PCC 7120 and reached 2 times higher cell concentration than medium without fructose during 12 days.

The use of galactose as a source of organic carbon for the production of biomass for the genus Anabaena is rarely reported in the literature, although it shows a good conversion for cell growth. Other sources of carbon, such as mannose and xylose are reported, but they have caused a decrease in the concentration of cyanobacterial biomass (Sahu et al., 2007). 


\subsection{PC production}

To determine the presence of phycocyanin in the extract of the strain of Anabaena variabilis, a spectral scan was performed, as shown in Figure 2.

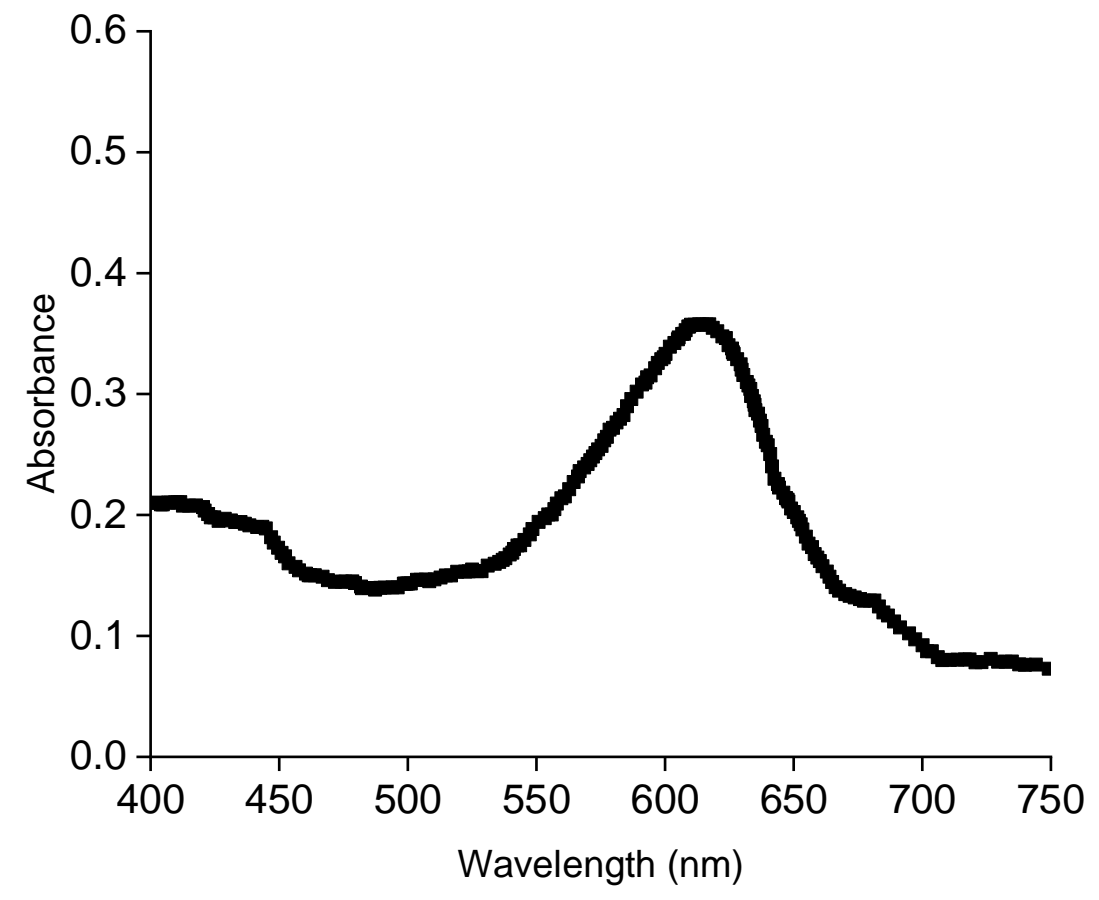

Figure 2 - Spectral scan of crude extract for Anabaena variabilis.

According to Figure 2, the presence of a peak in the region of $610-620 \mathrm{~nm}$ can be observed, a peak region characteristic of $\mathrm{PC}$, indicating its presence in the crude extract (Rizzo et al., 2015).
The effect of sugar supplementation to the basal medium (BG110) on the production of phycocyanin by Anabaena variabilis is shown in Figure 3.

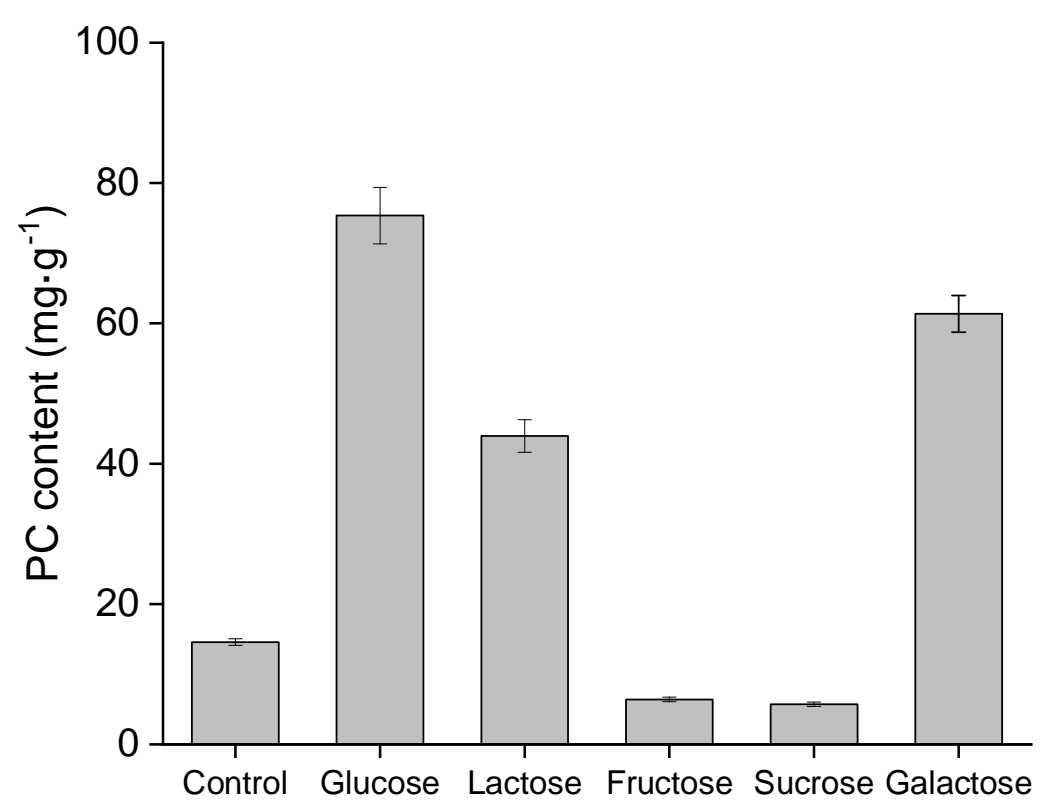

Figure 3 - Phycocyanin concentration obtained by supplementing the basal medium with different carbon sources after 8 days. Values are means \pm standard deviation. 
According to Figure 3, cultures containing glucose, lactose and galactose favored the increase of phycocyanin concentration, with a higher content in comparison to the assay using control medium. In contrast, cultivation in media containing fructose and sucrose hindered its production.

The highest concentration of PC was obtained for the medium containing glucose, reaching $75.36 \mathrm{mg} \mathrm{g}^{-1}$, presenting an increase of 5.2 times in relation to the control medium. Other significant concentrations were obtained by galactose with $61.36 \mathrm{mg} \mathrm{g}^{-1}$ and lactose with $43.94 \mathrm{mg} \square \mathrm{g}^{-1}$, respectively 4.2 and 3 times higher than the control medium.

The media supplemented with fructose and sucrose showed no significant difference, with concentrations in the order of $6 \mathrm{mg} \mathrm{g}^{-1}$ of PC, a value about $40 \%$ lower than the control medium. This result indicates that the consumption of these carbon sources does not indicate a higher production of phycocyanin (Figure 3) and biomass production (Figure 2), since fructose was the most consumed sugar, indicating that different metabolic routes were used by cyanobacteria in function of the carbon source.

The optimum source of organic carbon supplemented to the culture medium of cyanobacteria in order to obtain PBP, more specifically PC, is also variable in the literature. Khattar et al. (2015), also studied the synthesis of PBP by supplementing the culture medium for Anabaena fertilissima. Their work showed that better results were obtained when fructose and sucrose were added to the media, being 2.9 and 2.5 times higher than in the assay with glucose. Kaushal et al. (2017), that used Nodularia sphaerocarpa, found that the basal culture medium (Chu-10) plus $0.5 \%$ glucose was able to increase the PC concentration by about 1.9 times in relation to the medium control. In the work developed by Cottas et al. (2020), that used Anabaena variabilis and analyzed the supplementation of glucose and sodium nitrate isolated and simultaneously, proved that medium supplemented with only glucose $1 \mathrm{~g} \square \mathrm{L}^{-1}$ enable to attain PC concentration of $77.68 \mathrm{mg} \cdot \mathrm{g}^{-1}$ in 10 days of cultivation.

The synthesis of phycobiliproteins by cyanobacteria in the presence of lactose and galactose as organic sources of carbon is still little explored in the literature and the present work indicates positive results. All these sugars tested in the current study are present in agroindustrial residues or byproducts and they are an alternative of low-cost feedstock, as cheese whey, sugarcane and soybean molasses or fruit processing residue. Kabariya and Ramani (2018) investigated dairy wastewater treatment by Oscillatoria sp., Phormidium sp. and its co-culture system and observed PC concentration of 0.13 , 0.03 and $0.10 \mathrm{mg} \mathrm{L}^{-1}$, respectively. According to Hung et al. (2005), dairy wastewater has high organic loading rate, with the main contributors being lactose.

Comparing this work with the literature, it is observed that the species of cyanobacteria is also a variable to be considered in the evaluation of PC production, and the species may present different metabolisms according to the composition of the culture medium and the type of source of supplemented organic carbon (Pagels et al., 2019), causing different production of metabolites.

The production of PC with only one variable, the carbon source, is a step towards future stages with the combination of several factors that influence the production of phycocyanin, such as the $\mathrm{pH}$ of the medium, supplementation of nitrogen sources, sources of phosphorus, photoperiod, intensity and quality of light.

\section{CONCLUSION}

The present work indicates that Anabaena variabilis grown in a mixotrophic medium has different assimilations to different sources of organic carbon, suffering changes in cell growth and phycocyanin production. It is concluded that the best condition is supplementation with $\mathrm{BG} 11_{0}$ medium with glucose, with cell concentration 2 times higher and favoring the production of PC about 5 times during 8 days of culture, compared to the control medium.

\section{AKCNOWLEDGMENTS}

The authors acknowledge CAPES, CNPq and FAPEMIG from Brazil for financial support.

\section{R E F E R E N C E S}

ARYEE, A. N. A.; AGYEI, D., AKANBI, T. O. Recovery and Utilization of Seaweed Pigments in Food Processing. Current Opinion in Food Science, v. 19, p. 113-119, 2018.

BORSARI, R. R. J.; MORIOKA, L. R.; RIBEIRO, M. L. L.; BUZATO, J. B. Mixotrophic growth of Nostoc sp. on glucose, sucrose and sugarcane molasses for Phycobiliprotein production. Acta Scientiarum Biological Sciences, Maringá, PR, v. 29, n. 1, p. 9-13, 2007.

CHEN, P.; FAN, S.; CHIANG, C.; LEE, C. Effect of growth conditions on the hydrogen production with cyanobacterium Anabaena sp. strain CH3. International Journal of Hydrogen Energy, v. 33, n.5, p. 1460ї 1464, 2008.

COTTAS, A. G.; CUNHA, W. R.; RIBEIRO, E. J.; FERREIRA, J. S. Influence of Medium Composition on the Production of Phycocyanin from Anabaena variabilis. Industrial Biotechnology, v. 16, n. 2, p. 45-49, 2020.

HEMLATA; FATMA T. Screening of cyanobacteria for phycobiliproteins and effect of different environmental stress on its yield. Bulletin of environmental contamination and toxicology, v. 38, p. 509-515, 2009.

HUNG, Y.-T.; BRITZ, T.; VAN SCHALKWYK, C. Treatment of Dairy Processing Wastewaters. Waste Treatment in the Food Processing Industry, v.1, p. 1 ï 28, 2005.

\̦TER, I.; AKYIL, S.; DEMIREL, Z.; KOÇ, M.; CONKDALAY, M.; KAYMAK-ERTEKIN, F. Optimization of phycocyanin extraction from Spirulina platensis using 
different techniques. Journal of Food Composition and Analysis, v. 70, p. 78ї 88, 2018.

JAISWAL, P.; SINGH, P. K.; PRASANNA, R. Cyanobacterial bioactive molecules: an overview of their toxic properties. Canadian Journal of Microbiology, v. 54, n.9, p. 701-717, 2008.

KABARIYA, J. H.; RAMANI, V. M. Dairy Wastewater Treatment by Cyanobacteria for Removal of Nutrients with Extraction of High Value Compounds from Biomass. International Journal of Current Microbiology and Applied Sciences, v. 7, n. 4, p. 1527 1538, 2018.

KAUSHAL, S.; SINGH, Y.; KHATTAR, J. I. S.; SINGH, D. P. Phycobiliprotein production by a novel cold desert cyanobacterium Nodularia sphaerocarpa PUPCCC 420. Journal of Applied Phycology, v29, n.4, p 1819-1827, 2017.

KHATTAR, J. I. S.; KAUR, S.; KAUSHAL, S.; SINGH, Y.; SINGH, D. P.; RANA, S.; GULATI, A. Hyperproduction of phycobiliproteins by the cyanobacterium Anabaena fertilissima PUPCCC 410.5 under optimized culture conditions. Algal Research., v. 12, p. 463ї 469, 2015.

KHAZI, M. I.; DEMIREL, Z.; DALAY, M. C. Evaluation of growth and phycobiliprotein composition of cyanobacteria isolates cultivated in different nitrogen sources. Journal of Applied Phycology, v. 30, n. 3, p. 1513-1523, 2018.

KHETKORN, W.; LINDBLAD, P.; INCHAROENSAKDI, A. Enhanced biohydrogen production by the N2-fixing cyanobacterium Anabaena siamensis strain TISTR 8012. International Journal of Hydrogen Energy, v. 35, n. 23, p. $12767 і ̈$ 12776, 2010.

KHETKORN, W.; LINDBLAD, P.; INCHAROENSAKDI, A. Enhanced $\mathrm{H}_{2}$ production with efficient $\mathrm{N}_{2}$-fixation by fructose mixotrophically grown Anabaena sp. PCC 7120 strain disrupted in uptake hydrogenase. Algal Research, v. 47, p. 101823, 2020.

KOVAL,, D.; BABIĹ, O.; MILOVANOVIĹ, I.; MIĠAN, A.; SIMEUNOVIL, J. The production of biomass and phycobiliprotein pigments in filamentous cyanobacteria: the impact of light and carbon sources. Applied Biochemistry and Microbiology, v. 53, n. 5, p. 539ї 545, 2017.

KUMAR, D.; DHAR, D. W.; PABBI, S.; KUMAR, N.; WALIA, S. Extraction and purification of Cphycocyanin from Spirulina platensis (CCC540). Indian Journal of Plant Physiology, v. 19, n. 2, p. 184ї 188, 2014.

LAUCERI, R.; CHINI ZITTELLI, G.; MASERTI, B.; TORZILLO, G. Purification of phycocyanin from Arthrospira platensis by hydrophobic interaction membrane chromatography. Algal Research, v. 35, p. 333 ï 340, 2018.

MANIRAFASHA, E.; NDIKUBWIMANA, T.; ZENG, X.; LU, Y.; JING, K. Phycobiliprotein: Potential microalgae derived pharmaceutical and biological reagent. Biochemical Engineering Journal, v. 109, p. 282ï 296, 2016.

MUÑOZ-MARÍN, M.C.; GÓMEZ-BAENA， G.; LÓPEZ-
LOZANO, A.; MORENO-CABEZUELO, J. A.; DÍEZ, J.; GARCÍA-FERNÁNDEZ, J. M. Mixotrophy in marine picocyanobacteria: use of organic compounds by Prochlorococcus and Synechococcus. ISME Journal, v. 14, p. 1065 Ï 1073, 2020.

NOREÑA-CARO, D., BENTON, M. G. Cyanobacteria as photoautotrophic biofactories of high-value chemicals. Journal of CO2 Utilization, v. 28, p. 335-366, 2018.

OLAIZOLA, M. Commercial development of microalgal biothecnology: from the test tube to the marketplace. Biomolecular Engineering, v. 20, p. 359-466, 2003.

PAGELS, F.; GUEDES, A. C.; AMARO, H. M.; KIJJOA, A.; VASCONCELOS, V. Phycobiliproteins from cyanobacteria: Chemistry and biotechnological applications. Biotechnology Advances, v. 37, n. 3, p. 422-443, 2019.

PRASANNA R.; PABBY A.; SINCH P. K. Effect of glucose and light-dark environment on pigmentation profiles in the cyanobacterium Calothrix elenkenii. Folia Microbiologica, v. 49, n. 1, p. 26ï 30, 2004.

RASTOGI, R. P.; SONANI, R. R.; PATELA, A. B.; MADAMWAR, D. Occurrence of a Functionally Stable Photoharvesting Single Peptide Allophycocyanin U subunit (16.4 $30 \mathrm{kDa}$ ) in the Cyanobacterium Nostoc sp. R76DM. RSC Advances, v. 5, n.106, p. 87598- 87608, 2015.

RIPPKA, R.; STANIER, R. Y.; DERUELLES, J.; HERDMAN, M.; WATERBURY, J. B. Generic Assignments, Strain Histories and Properties of Pure Cultures of Cyanobacteria. Microbiology, v. 111, n. 1, p. 1 ï 61, 1979.

RIZZO, R. F.; SANTOS, B. DO N. C. DOS; CASTRO, G. F. P. DA S. DE; PASSOS, T. S.; NASCIMENTO, M. DE A.; GUERRA, H. D.; LIMA-ARAÚJO, K. G. DE. Production of phycobiliproteins by Arthrospira platensis under different lightconditions for application in food products. Food Science and Technology, v. 35, n.2, p. 247ї 252, 2015.

SAHU, J.; ADHIKARY, S. P. Heterotrophic growth and nitrogen fixation in the filamentous blue-green alga Anabaena sp. Zeitschrift Für Allgemeine Mikrobiologie, v. 21, n. 9, p. 669ї 676, 2007.

SCHRADER, K. K.; DAYAN, F. E. Antioxidant Enzyme Activities in the Cyanobacteria Planktothrix agardhii, Planktothrix perornata, Raphidiopsis brookii, and the Green Alga Selenastrum capricornutum. In: GAULT, P. M.; MARLER, H. J. Handbook on Cyanobacteria: biochemistry, biotechnology and applications. Nova York: Nova Science Publishers, 2009.

SKLERYK, R. S.; SO, A. K.; ESPIE, G. S. Effects of carbon nutrition on the physiological expression of $\mathrm{HCO}_{3}$ transport and the $\mathrm{CO}_{2}$-concentrating mechanism in the Cyanobacterium Chlorogloeopsis sp. ATCC 27193. Planta, v. 214, n. 4, p. 572-583, 2002.

STAL, L. J. Cyanobacteria: diversity and versatility - Clues to life in extreme Environments. In: J. SECKBACH. Algae and Cyanobacteria in Extreme Environments, Dordrecht: Springer, 2007.

TAN, L. T. Bioactive natural products from marine cyanobacteria for drug discovery. Phytochemistry, v. 
68, p. 954ї 979, 2007.

VARGAS, S. R.; SANTOS, P. V. DOS; ZAIAT, M.; CALIJURI, M. DO C. Optimization of biomass and hydrogen production by Anabaena sp. (UTEX 1448) in nitrogen-deprived cultures. Biomass and Bioenergy, v. 111, p. 70Ï 76, 2018.

VISKARI, P. J.; COLYER, C. L. Rapid extraction of Phycobiliproteins from cultured Cyanobacteria samples. Analytical Biochemistry, v. 319, n.2, p. 263-271, 2003.

WHITTON, B.A.; POTTS, M. The Ecology of Cyanobacteria: Their Diversity in Time and Space. Kluwer Academic Publisher, 2012. 